\title{
Pengaruh Profitabilitas Dan Likuiditas Terhadap Laba Sebelum Pajak (Studi Pada PT IMS Jakarta)
}

\author{
Sabil,Amin Setio Lestiningsih, Dwiyatmoko Puji Widodo, Apriyanto \\ Universitas Bina Sarana Informatika, Indonesia \\ E-mail: sabil.sbl@bsi.ac.id
}

\begin{abstract}
Abstrak
Tujuan penelitian adalah untuk mengetahui pengaruh profitabilitas (Return on Assets/ROA) dan likuiditas (Current Ratio/CR) terhadap laba sebelum pajak (EBT) pada PT IMS Jakarta periode tahun 2014-2018.PT. Inti Megah Swara (IMS) adalah salah satu perusahaan distributor merk audio kelas dunia di Indonesia.Metode yang digunakan dalam penelitian ini adalah metode deskriptif dengan pendekatan kuantitatif.Untuk mengetahui pengaruh profitabilitas dan likuiditas terhadap laba sebelum pajak digunakan pengujian statistik.Metode Pengujian yangdigunakan adalah uji koefisien korelasi, persamaan regresi, koefisien determinasi, uji multikolineritas, uji normalitas serta uji persamaan regresi secara parsial. Nilai profitabilitas dan likuiditas sebagai variabel independent.Berdasarkanhasil analisis data disimpulkan bahwa ROAmemiliki tingkat korelasi sangat erat terhadap EBT.Sedangkan CR memiliki tingkat korelasi erat terhadap EBT. ROA dan CR secara bersama-sama atau simultan tidak berpengaruh terhadap EBT.
\end{abstract}

Kata kunci: Return On Assets, Current Ratio, Earning Before Tax

\section{Pendahuluan}

Kondisi perusahaan yang sehat tidak hanya dilihat dari fisik bangunan, tetapi dilihat dari segi financial terutama aspek kinerja keuangan perusahaan tersebut. Kondisi keuangan ini menjadi salah satu unsur untuk mengevaluasi apakah kebijakan yang selama ini ditempuh pihak manajemen sudah tepat atau justru tidak sesuai harapan.Hal ini perlu dilakukan mengingat sudah banyak perusahaan yang mengalami kebangkrutan karena 1ariab keuangan yang tidak sehat.Inilah yang membuat analisis kinerja keuangan begitu penting dilaksanakan.

Analisis kinerja keuangan pada dasarnya dibuat untuk mendapatkan gambaran berupa prospek dan risiko perusahaan. Prospek dapat dilihat dengan cara menghitung tingkat keuntungan (profitabilitas), sedangkan risiko dilihat dari kemungkinan perusahaan mengalami kesulitan keuangan atau mengalami kebangkrutan. Profitabilitas atau return on equity dihitung dengan mengukur penghasilan atau income yang tersedia bagi pemilik perusahaan atas modal yang mereka investasikan di dalam perusahaan. Profitabilitas juga dianggap sebagai ukuran pokok keseluruhan keberhasilan perusahaan.

Selain itu, setiap perusahaan baik itu skala besar maupun kecil harus memperhatikan likuiditas atau liquidity.Tanpa mengetahui likuiditas, pemilik perusahaantidak akan pernah tahu berapa lama dapat membiayai perusahaan agar tetap berjalan. Likuiditas adalah kemampuan perusahaan memenuhi kewajiban finansialnya setiap saat.

Perusahaan juga dituntut untuk mampu menghasilkan laba sesuai dengan kurun waktu yang telah ditetapkan.Kemampuan perusahaan memperoleh laba dipengaruhi oleh pendapatan yang diperoleh lebih besar dari biaya yang dikeluarkan. Laba sebuah perusahaan berarti menunjukkan eksistensi perusahaan tersebut.Semakin tinggi laba yang dicapai, maka orang-orang cenderung percaya bahwa perusahaan itu mampu betahan di tengah-tengah persaingan.

Ketiga unsur tersebut, baik profitabilitas, likuiditas, serta laba dapat dianalisa melalui laporan keuangan perusahaan.Laporan keuangan harus disajikan secara rinci, termasuk didalamnya adalah laporan laba rugi, yang menggambarkan hasil operasi atau kinerja perusahaan.Salah satu variabel 1 dalam melakukan kajian laporan keuangan adalah dengan melihat laba sebelum pajak.Penggunaan laba sebelum pajak dimaksudkan untuk menghindari pengaruh penggunaan tarif pajak yang berbeda antar periode yang dianalisis. Laba sebelum pajak atau Earning before Tax 
(EBT) dapat didefinisikan sebagai uang yang disimpan oleh perusahaan sebelum dikurangi karena harus membayar kewajiban pajak. Dengan menghapus tarif pajak, maka akan sangat membantu untuk meminimalkan tarif pajak yang mungkin berbeda di berbagai perusahaan.

\section{Tinjauan Literatur}

\subsection{Pengertian Rasio Keuangan}

Kondisi keuangan suatu perusahaan dapat di analisis salah satunya dengan cara menghitung dan membandingkan rasio-rasio keuangan. Rasio-rasio keuangan tersebut dapat digunakan untuk membandingkan hasil laporan keuangan dan melihat adanya hubungan antara informasi keuangan. Adapun pengertian rasio keuangan menurut beberapa ahli, sebagai berikut:

Menurut Kasmir (2018:104) rasio keuangan adalah:

Kegiatan membandingkan angka-angka yang ada dalam laporan keuangan dengan cara membagi satu angka dengan angka lainnya. Perbandingan dapat dilakukan antara satu komponen dengan komponen dalam satu laporan keuangan atau antar komponen yang ada diantara laporan keuangan.Kemudian angka yang diperbandingkan dapat berupa angkaangka dalam satu periode maupun beberapa periode.

Sedangkan menurut Hery (2018:138) "Rasio keuangan adalah angka yang diperoleh dari hasil perbandingan antara satu pos laporan keuangan dengan pos lainnyayang mempunyai hubungan yang relevan dan signifikan."

\subsection{Jenis-Jenis Rasio Keuangan}

Rasio keuangan dipergunakan oleh pihak manajemen perusahaan untuk membandingkan rasio pada saat sekarang dengan rasio pada saat yang akan datang. Adapun bagi investor adalah membandingkan rasio keuangan suatu perusahaan/industri dengan perusahaan/industri lain yang sejenis dengan maksud nantinya akan bias memberikan suatu analisis perbandingan yang memperlihatkan perbedaan dalam kinerja keuangan.

Menurut Fahmi dalam (Widayanti, 2018) ada tiga rasio keuangan yang paling dominan yang dijadikan rujukan untuk melihat kondisi kinerja suatu perusahaan, yaitu:

1. Rasio Profabilitas

Rasio profitabilitas adalah bermanfaat untuk menunjukkan keberhasilan perusahaan di dalam menghasilkan keuntungan. Investor yang potensial akan menganalisis dengan cermat kelancaran sebuah perusahaan dan kemampuannya untuk mendapatkan keuntungan (profitabilitas), karena mereka mengharapkan deviden dan harga pasar dari sahamnya. Rasio ini dimaksudkan untuk mengukur efisiensi penggunaan aktiva perusahaan. Rasio profitabilitas terdiri dari:
a. Gross Profit Margin
b. Net Profit Margin
c. Return on Assets
d. Return on Equity

2. Rasio Likuiditas

Rasio likuiditas adalah kemampuan perusahaan dalam memenuhi kewajiban jangka pendeknya.Rasio ini penting karena kegagalan dalam membayar kewajiban dapat menyebabkan kebangkrutan perusahaan.Rasio ini mengukur pada kemampuan likuiditas jangka pendek perusahaan dengan melihat aktiva lancar perusahaan relatif terhadap utang lancarnya (utang yang dimaksud di sini adalah kewajiban perusahaan). Rasio likuiditas terdiri dari:
a. Current Ratio
b. $\quad$ Quick Ratio atau Acid Test Ratio
c. Net Working Capital Ratio
d. Cash Flow Liquidity Ratio 


\section{Rasio Solvabilitas}

Rasio solvabilitas atau leverage ratio merupakan rasio yang menunjukkan bagaimana perusahaan mampu untuk mengelola utangnya dalam rangka memperoleh keuntungan dan juga mampu untuk melunasi kembali utangnya. Rasio ini mengukur kemampuan perusahaan memenuhi kewajiban-kewajiban dalam jangka panjangnya. Perusahaan yang tidak solvabel adalah perusahaan yang total utangnya lebih besar dibandingkan total asetnya. Namun harus dipahami bahwa bukan berarti perusahaan yang insolvabel namun likuid tapi tidak bisa menjalankan aktivitasnya.Karena dengan kemampuan likuiditas yang dimiliki sangat memungkinkan perusahaan tersebut untuk bisa mengembalikan utangnya dengan cepat. Rasio Solvabilitas terdiri dari:
a. Debt to Total Asset atau Debt Ratio
b. Debt to Equity Ratio
c. Times Interest Earned
d. Cash Flow Coverage
e. Long-Term Debt to Total Capitalization
f. Fixed Charge Coverage
g. Cash Flow Adequacy

\subsection{Pengertian Rasio Profitabilitas}

Pada umumnya tujuan akhir yang ingin dicapai setiap perusahaan adalah memperoleh keuntungan yang maksimal.Oleh karena itu, perusahaan dituntut harus mampu memenuhi target yang telah ditetapkan. Keuntungan yang diperoleh harus sesuai dengan target yang diharapkan, namun bisa saja terjadi perubahan karena situasi dan kondisi yang terjadi di masa depan. Untuk mengukur tingkat kemampuan suatu perusahaan dalam memperoleh keuntungan, biasanya menggunakan rasio profitabilitas.Semakin baik rasio profitabilitas maka semakin baik menggambarkan kemampuan tingginya perolehan keuntungan perusahaan.

Menurut Hanafi (2018:81) rasio profitabilitas berarti mengukur kemampuan perusahaan menghasilkan keuntungan (profitabilitas) pada tingkat penjualan, aset, dan modal saham tertentu. Sedangkan menurut Kasmir (2018:114) rasio profitabilitas adalah "Rasio untuk menilai kemampuan perusahaan dalam mencari keuntungan. Rasio ini juga memberikan ukuran tingkat efektivitas manajemen suatu perusahaan.Hal ini ditunjukkan oleh laba yang dihasilkan dari penjualan dan pendapatan investasi.Intinya penggunaan rasio ini menunjukkan efisiensi perusahaan".

\subsection{Pengukuran Rasio Profitabilitas}

Menurut Hery (2018:193) Return on Assets (ROA) digunakan untuk mengukur seberapa besar jumlah laba bersih yang akan dihasilkan dari setiap rupiah dana yang tertanam dalam total asset.

Rumus yang digunakan untuk mencari Return on Asset adalah:

$$
\text { Return on Assets }(\mathrm{ROA})=\frac{\text { EAT }}{\text { Total Assets }} \times 100 \%
$$

Keterangan:

$$
\begin{array}{ll}
\text { Return on Asset }(\mathrm{ROA}) & \text { = Rasio Tingkat Profitabilitas } \\
\text { Laba Bersih } & \text { Jumlah laba bersih perusahaan setelah pajak } \\
\text { Total Aset } & \text { Jumlah aset yang dimiliki perusahaan }
\end{array}
$$

Berdasarkan penelitian yang dilakukan (Deviani \& Sudjarni, 2018) menyatakan bahwa profitabilitas memiliki pengaruh negatif dan signifikan terhadap struktur modal perusahaan pertambangan di Bursa Efek Indonesia dan likuiditas memiliki pengaruh negatif dan signifikan terhadap struktur modal perusahaan pertambangan di Bursa Efek Indonesia. 


\subsection{Pengertian Rasio Likuiditas}

Rasio likuiditas merupakan alat untuk mengukur kemampuan perusahaan dalam membayar utang jangka pendeknya dengan menggunakan aset lancarnya. Menurut Kasmir (2018:130) "Rasio likuiditas atau sering juga disebut dengan nama rasio modal kerja merupakan rasio yang digunakan untuk mengukur seberapa likuidnya suatu perusahaan."

Likuiditas mengacu pada kesanggupan perusahaan membiayai kewajibannya dilihat dari posisi keuangan secara keseluruhan. Rasio likuiditas dapat memberikan tanda awal mengenai masalah arus kas dan kegagalan usaha yang akan dihadapi perusahaan di masa mendatang karena tanda awal dari terjadinya kesulitan keuangan dan kebangkrutan adalah nilai likuiditas yang rendah atau menurun (Supena, 2018).

\subsection{Pengukuran Rasio Likuiditas}

Untuk mengukur likuiditas perusahaan, dalam penelitian ini rasio yang digunakan adalah current ratio $(\mathrm{CR})$.

Menurut Kasmir (2018:134), current ratio (CR) atau rasio lancar adalah "Rasio untuk mengukur kemampuan perusahaan dalam membayar kewajiban jangka pendek atau utang yang segera jatuh tempo pada saat ditagih secara keseluruhan. Dengan kata lain, seberapa banyak aktiva lancar yang tersedia untuk menutupi kewajiban jangka pendek yang segera jatuh tempo".

Pernyataan tersebut menjelaskan bahwa secara umum, semakin besar nilai rasio lancar atau current ratio, maka semakin likuid perusahaan tersebut.Semakin besar arus kas perusahaan dapat diprediksi, maka semakin rendah nilai rasio yang lancar dapat diterima.

Current ratio

Current rasio adalah rasio yang membandingkan antara aktiva lancar yang dimiliki perusahaan dengan utang jangka pendek.Aktiva lancar disini meliputi kas, piutang dagang, efek, persediaan, dan aktiva lancar lainnya. Sedangkan utang jangka pendek meliputi utang dagang, utang wesel, utang bank, utang gaji, dan utang lainnya yang segera harus dibayar.

Rumus current ratio adalah:

$$
\text { Current ratio }=\frac{\text { Aset Lancar }}{\text { Hutang Lancar }} \times 100 \%
$$

Keterangan:

Current ratio

Aset lancar

Hutang lancar

$=$ tingkat current ratio

$=$ jenis aset yang digunakan dalam jangka waktu dekat

= hutang yang dibayar dalam jangka waktu satu tahun

Berdasarkan penelitian yang dilakukan (Rohmiyati, Wijayanti, \& Nurlaela, 2017) Pengaruh Current Ratio Terhadap Struktur Modal disimpulkan bahwa variabel current ratio (CR) berpengaruh terhadap struktur modal.

\subsection{Laba Bersih Sebelum Pajak}

Laba bersih sebelum pajak secara umum adalah ukuran dari profitabilitas suatu perusahaan yang tidak termasuk beban pajak penghasilan (Siswanti \& Kharima, 2016).

Menurut Golrida Karyawati dalam (Siswanti \& Kharima, 2016)"Pengertian laba bersih sebelum pajak adalah sebagai uang yang disimpan oleh perusahaan sebelum dikurangi karena harus membayar pajak."

Laba bersih sebelum pajak memberikan informasi analisis investasi yang bermafaat untuk mengevaluasi kinerja operasi perusahaan tanpa memperhatikan pengaruh pajak. Dengan menghapus faktor pajak, tentu laba bersih sebelum pajak atau Earning Before Tax (EBT) akan 
lebih berfokus kepada analisis profitabilitas operasi sebagai ukuran tunggal kinerja perusahaan (Siswanti \& Kharima, 2016).

Rumus umum untuk menentukan EBT:

EBT $=$ Pendapatan - Beban (tidak termasuk pajak)

Keterangan:

EBT = Earning Before Tax

Pendapatan

$=$ hasil yang diperoleh dari kegiatan perusahaan

Beban

= pengurang dari pendapatan

\section{Metodologi Penelitian}

Penelitian ini menggunakan pendekatan kuantitatif, yaitu penelitian yang memfokuskan pada pengujian hipotesis, dengan menggunakan data yang dapat diukur untuk mengambil kesimpulan dan yang menjadi objek penelitian adalah PT. IMS Jakarta. Populasi yang digunakan dalam penelitian ini adalah laporan keuangan dari tahun 2014 sampai dengan 2018 dengan menghitung rasio return on assets, current rasio dan rasio earning before tax. Teknik Analisis data menggunakan SPSS untuk uji koefesien korelasi, dimana variabel $X_{1}$ adalah rasio return on asserts, variabel $\mathrm{X}_{2}$ adalah current rasio sedangkan variabel $\mathrm{Y}$ adalah earning before tax. Pengujian yang dipakai untuk menguji data ini dengan menggunakan uji klasik berupa uji multikolineritas dan uji normalitas.

\section{Hasil dan Pembahasan}

\subsection{Data Penelitian}

\subsubsection{Data Variabel X}

Data variabel $\mathrm{X}$ pada penelitian ini terdapat dua variabel bebas yaitu data variabel $\mathrm{X}_{1}$ adalah data laporan keuangan perusahaan untuk memperoleh rasio profitabilitas. Pada penelitian ini rasio yang digunakan untuk mengukur profitabilitas adalah Return on Assets (ROA). Sedangkan data variabel $\mathrm{X}_{2}$ adalah data laporan keuangan perusahaan untuk memperoleh rasio likuiditas.Untuk mengukur likuiditas perusahaan, dalam penelitian ini rasio yang digunakan adalah current ratio (CR).

\section{Data Return on Assets (ROA)}

ROA adalah rasio yang menunjukan koefesienan perusahaan dalam mengolah sejumlah aset yang dimiliki oleh perusahaan untuk mendapatkan laba. ROA diperoleh dengan cara membandingkan laba sebelum pajak dengan total asset koperasi. Berikut merupakan tabel yang berisikan data untuk memperoleh rasio ROA, perhitungan dilakukan oleh penulis berdasarkan data yang diperoleh dari laporan keuangan perusahaan dari tahun 2014 sampai dengan 2018:

\section{Tabel 1}

Return on Assets (ROA)

\begin{tabular}{ccc}
\hline Tahun & ROA & Loan \\
\hline 2014 & 8,22 & 2,11 \\
\hline 2015 & 35,63 & 3,57 \\
\hline 2016 & 15,06 & 2,71 \\
\hline 2017 & 29,10 & 3,37 \\
\hline 2018 & 31,74 & 3,46
\end{tabular}

Sumber: Data Olah Peneliti (2019) 


\section{Data Current Ratio (CR)}

CR adalah rasio yang membandingkan antara aktiva lancar yang dimiliki perusahaan dengan utang jangka pendek. CR diperoleh dengan cara membandingkan aktiva lancar yang meliputi kas, piutang usaha, piutang lainnya, dan aktiva lancar lainnya, dengan hutang jangka pendek meliputi hutang usaha dan pembayaran pajak PPh Pasal 25/29yang harus dibayar. Berikut merupakan tabel yang berisikan data untuk memperoleh current ratio, perhitungan dilakukan oleh penulis berdasarkan data yang diperoleh dari laporan keuangan perusahaan dari tahun 2014 sampai dengan 2018:

Tabel 2

Current Ratio (CR)

\begin{tabular}{ccc}
\hline Tahun & CR & Loan \\
\hline 2014 & 267,63 & 5,59 \\
\hline 2015 & 811,16 & 6,70 \\
\hline 2016 & 294,06 & 5,68 \\
\hline 2017 & 515,68 & 6,25 \\
\hline 2018 & 307,88 & 5,73 \\
\hline
\end{tabular}

Sumber: Data Olah Peneliti (2019)

\section{Data Variabel Y}

Data variabel Y pada penelitian ini adalah laba sebelum pajak atau Earning Before Tax (EBT) perusahaan. Laba memiliki peran penting bagi perusahaan sebagai cara untuk menunjukkan prestasi dan untuk kelangsungan hidup perusahaan. Laba juga sering dijadikan alat ukur investasi.Laba sebelum pajak di peroleh dengan mengurangkan pendapatan yang diperoleh dengan biaya yang dikeluarkan (tidak termasuk pajak). Berikut merupakan tabel yang berisikan data laba perusahaan, data yang diperoleh dari tahun 2014 sampai dengan 2018:

Tabel 3

Laba Sebelum Pajak (EBT) Perusahaan 2014-2018

\begin{tabular}{ccc}
\hline Tahun & $\begin{array}{c}\text { Laba sebelum pajak } \\
\text { (dalam Rupiah) }\end{array}$ & Loan \\
\hline 2014 & 1.217 .832 .880 & 20,92 \\
\hline 2015 & 2.243 .085 .749 & 21,53 \\
\hline 2016 & 1.014 .297 .764 & 20,74 \\
\hline 2017 & 2.167 .945 .191 & 21,50 \\
\hline 2018 & 2.253 .132 .206 & 21,54 \\
\hline
\end{tabular}

Sumber: PT IMS

\section{Tabel Penolong}

Tabel penolong adalah kumpulan angka-angka yang disusun menurut kategori-kategori hingga memudahkan dalam pembuatan analisis data.Tabel bisa memberikan angka-angka yang lebih rinci tapi tidak bisa dengan cepat diambil kesimpulannya. Berikut merupakan tabel penolong yang digunakan dalam penelitian, adalah:

Tabel 4

Tabel Penolong

\begin{tabular}{cccccccccc}
\hline Tahun & $\begin{array}{c}\text { ROA } \\
\left(\mathbf{X}_{\mathbf{1})}\right.\end{array}$ & $\begin{array}{c}\mathbf{C R} \\
\left(\mathbf{X}_{2)}\right.\end{array}$ & $\begin{array}{c}\mathbf{E B T} \\
(\mathbf{Y})\end{array}$ & $\mathbf{X}_{\mathbf{1}}{ }^{2}$ & $\mathbf{X}_{\mathbf{2}}{ }^{2}$ & $\mathbf{Y}^{\mathbf{2}}$ & $\mathbf{X}_{\mathbf{1}} \mathbf{Y}$ & $\mathbf{X}_{\mathbf{2}} \mathbf{Y}$ & $\mathbf{X}_{\mathbf{1}} \mathbf{X}_{\mathbf{2}}$ \\
\hline 2014 & 2,11 & 5,59 & 20,92 & 4,45 & 31,25 & 437,65 & 44,14 & 116,94 & 11,79 \\
\hline
\end{tabular}




\begin{tabular}{cccccccccc}
\hline 2015 & 3,57 & 6,70 & 21,53 & 12,74 & 44,89 & 463,54 & 76,86 & 144,25 & 23,92 \\
\hline 2016 & 2,71 & 5,68 & 20,74 & 7,34 & 32,26 & 430,15 & 56,21 & 117,80 & 15,39 \\
\hline 2017 & 3,37 & 6,25 & 21,5 & 11,36 & 39,06 & 462,25 & 72,46 & 134,38 & 21,06 \\
\hline 2018 & 3,46 & 5,73 & 21,54 & 11,97 & 32,83 & 463,97 & 74,53 & 123,42 & 19,83 \\
\hline$\sum$ & 15,22 & 29,95 & 106,23 & 47,87 & 180,30 & 2257,56 & 324,19 & 636,80 & 92,00 \\
\hline
\end{tabular}

Sumber: Data Olah Peneliti (2019)

\subsection{Analisis Pengaruh ROA dan CR Terhadap EBT \\ 4..2.1 Uji Koefisien Korelasi}

Uji koefeisien korelasi digunakan untuk membuktikan keeratan hubungan atau korelasi antara dua variabel bebas yaitu $\mathrm{X}_{1}$ dan $\mathrm{X}_{2}$ terhadap variabel terikat yaitu $\mathrm{Y}$. Apakah hubungan antara kedua variabel bebas dan terikat tersebut mempunyai hubungan yang kuat atau hubungan yang lemah.

Berdasarkan pengolahan data yang telah dilakukan dengan menggunakan SPSS 20 maka didapatkan hasil perhitungan sebagai berikut:

Ho: tidak ada hubungan signifikan antara rasio keuangan ROA dan CR tehadap EBT.

Ha: ada hubungan signifikan antara rasio keuangan ROA dan CR tehadap EBT.

Tabel 5

Hasil Analisis Koefisien Korelasi

Correlations

\begin{tabular}{|c|c|c|c|c|}
\hline & & EBT & ROA & CR \\
\hline \multirow{3}{*}{ Pearson Correlation } & EBT & 1,000 &, 866 &, 656 \\
\hline & ROA &, 866 & 1,000 & ,704 \\
\hline & CR & ,656 &, 704 & 1,000 \\
\hline \multirow{3}{*}{ Sig. (1-tailed) } & EBT & & ,029 &, 115 \\
\hline & ROA & ,029 & . & ,092 \\
\hline & CR &, 115 & ,092 & . \\
\hline \multirow{3}{*}{$\mathrm{N}$} & EBT & 5 & 5 & 5 \\
\hline & ROA & 5 & 5 & 5 \\
\hline & CR & 5 & 5 & 5 \\
\hline
\end{tabular}

Sumber: Data diolah dengan menggunakan SPSS versi 20

Berdasarkan tampilan output yang sudah diolah dapat diperoleh hubungan ROA terhadap EBT sangat erat positif sebesar 0,866. Sedangkan hubungan CR terhadap EBT korelasi erat positif sebesar 0,656 .

\subsubsection{Uji Koefisien Determinasi}

Koefisien determinasi ( $R$ Square atau R kuadrat) atau disimbolkan dengan " $R$ " , yang bermakna sebagai sumbangan pengaruh yang diberikan variabel bebas atau variabel independen (X) terhadap variabel terikat atau variabel dependen (Y). Atau dengan kata lain nilai koefisien determinasi atau $\mathrm{R}$ square ini berguna untuk memprediksi dan melihat seberapa besar kontribusi pengaruh yang diberikan variabel X secara simultan (bersama-sama) terhadap Y.

Persyaratan yang harus terpenuhi agar dapat memaknai nilai koefisien determinasi adalah hasil uji $\mathrm{F}$ bernilai signifikan.Sebaliknya jika hasil uji $\mathrm{F}$ tidak signifikan maka nilai koefisien determinasi tidak dapat digunakan atau dipakai untuk memprediksi kontribusi pengaruh variabel $\mathrm{X}$ secara simultan terhadap Y. 
Adapun hasil analisis regresi linear berganda (dalam uji F) dapat dilihat pada gambar tabel di bawah ini.

Tabel 6

\section{Uji Statistik F}

ANOVA $^{\text {a }}$

\begin{tabular}{llrrrrr}
\hline Model & & $\begin{array}{c}\text { Sum of } \\
\text { Squares }\end{array}$ & df & Mean Square & F & Sig. \\
\hline \multirow{2}{*}{1} & Regression &, 448 & 2 &, 224 & 3,062 &, $246^{\mathrm{b}}$ \\
\cline { 2 - 7 } & Residual &, 146 & 2 &, 073 & & \\
\cline { 2 - 7 } & Total &, 594 & 4 & & & \\
\hline
\end{tabular}

a. Dependent Variable: EBT

b. Predictors: (Constant), CR, ROA

Sumber: Data diolah dengan menggunakan spss versi 20

Berdasarkan tabel output ANOVA di atas diketahui bahwa nilai signifikan (Sig.) dalam uji F adalah sebesar 0,246. Karena sig 0,246 > 0,05, maka sebagaimana dasar pengambilan keputusan dalam uji $\mathrm{F}$ dapat disimpulkan bahwa ROA $\left(\mathrm{X}_{1}\right)$ dan $\mathrm{CR}\left(\mathrm{X}_{2}\right)$ secara simultan (bersama-sama) tidak berpengaruh terhadap EBT (Y) atau berarti tidak signifikan. Dengan demikian, maka persyaratan agar dapat memaknai nilai koefisien determinasi dalam analisis regresi linear berganda tidak terpenuhi.

\subsubsection{Uji Multikolineritas}

Uji Multikolineritas adalah uji yang dilakukan untuk memastikan apakah di dalam sebuah model regresi ada interkorelasi atau kolineritas antar variabel bebas.

Tabel 7

Coefficients $^{\mathrm{a}}$

\begin{tabular}{|c|c|c|c|c|c|c|c|c|c|c|c|}
\hline \multirow{2}{*}{\multicolumn{2}{|c|}{ Model }} & \multicolumn{2}{|c|}{$\begin{array}{l}\text { Unstandardized } \\
\text { Coefficients }\end{array}$} & \multirow{2}{*}{$\begin{array}{c}\begin{array}{c}\text { Standardiz } \\
\text { ed }\end{array} \\
\text { Coefficients }\end{array}$} & \multirow[t]{2}{*}{$t$} & \multirow[t]{2}{*}{ Sig. } & \multicolumn{3}{|c|}{ Correlations } & \multicolumn{2}{|c|}{$\begin{array}{l}\text { Collinearity } \\
\text { Statistics }\end{array}$} \\
\hline & & $B$ & Std. Error & & & & $\begin{array}{l}\text { Zero- } \\
\text { order }\end{array}$ & Partial & Part & $\begin{array}{c}\text { Toleran } \\
\text { ce }\end{array}$ & VIF \\
\hline \multirow{3}{*}{1} & $\begin{array}{l}\text { (Consta } \\
\mathrm{nt})\end{array}$ & 19.284 & 1.878 & & 10.266 & .009 & & & & & \\
\hline & $\begin{array}{l}\text { VAR000 } \\
01\end{array}$ & .498 & .307 & .801 & 1.621 & .247 & .866 & .753 & .569 & .504 & 1.985 \\
\hline & $\begin{array}{l}\text { VAR000 } \\
02\end{array}$ & .075 & .403 & .092 & .186 & .870 & .656 & .130 & .065 & .504 & 1.985 \\
\hline
\end{tabular}

a. Dependent Variable: VAR00003

Berdasarkan tabel di atas Nilai tolerance masing-masing variabel lebih dari 0,1 dan nilai VIF masing-masing variabel kurang dari 10 maka dapat disimpulkan bahwa tidak terjadi masalah multikolinearitas pada model regresi.

\subsubsection{Uji Normalitas}

Uji normalitas adalah sebuah ujiyangdilakukan dengan tujuan untuk menilai sebaran data pada sebuah kelompok data atau variabel, apakahsebaran data tersebut berdistribusi normal atau tidak. 
One-Sample Kolmogorov-Smirnov Test Unstandardized Residual

\begin{tabular}{llr}
\hline $\mathrm{N}$ & & 5 \\
\hline \multirow{2}{*}{ Normal Parameters $^{\mathrm{a}, \mathrm{b}}$} & Mean & .0000000 \\
\cline { 2 - 3 } & Std. Deviation & .19118781 \\
\hline \multirow{2}{*}{ Most Extreme Differences } & Absolute & .247 \\
\cline { 2 - 3 } & Positive & .189 \\
\cline { 2 - 3 } & Negative &. .247 \\
\hline Kolmogorov-Smirnov Z & & .553 \\
\hline Asymp. Sig. (2-tailed) & & .919
\end{tabular}

a. Test distribution is Normal.

b. Calculated from data.

Dari hasil uji normalitas diketahui bahwa nilai signifikansi (Asymp.Sig 2 - tailed) sebesar 0,919 . Karena signifikansi lebih dari $0,05(0,919>0,05)$ maka nilai residual terdistribusi secara normal atau memenuhi asumsi klasi knormalitas.

\subsubsection{Uji Persamaan Regresi Secara Parsial}

Analisa regresi digunakan untuk memprediksi atau menguji pengaruh satuvariabel bebas atau variabel independen terhadap variabel terkait atau variabel (dependent). Untuk menginterpretasikan koefisien variabel bebas (independent)dapat menggunakan unstandardized coefficients.Dari hasil analisis regresi output dapat disajikan sebagai berikut:

Tabel 7

Uji Statistik T

Coefficients $^{\mathrm{a}}$

\begin{tabular}{|c|c|c|c|c|c|c|}
\hline \multirow[t]{2}{*}{ Model } & & \multicolumn{2}{|c|}{ Unstandardized Coefficients } & \multirow{2}{*}{$\begin{array}{c}\text { Standardized } \\
\text { Coefficients } \\
\text { Beta } \\
\end{array}$} & \multirow[t]{2}{*}{$\mathrm{t}$} & \multirow[t]{2}{*}{ Sig. } \\
\hline & & B & Std. Error & & & \\
\hline \multirow{3}{*}{1} & (Constant) & 19,284 & 1,878 & & 10,266 & ,009 \\
\hline & ROA &, 498 & ,307 & ,801 & 1,621 & ,247 \\
\hline & $\mathrm{CR}$ & 075 & 403 &, 092 &, 186 &, 870 \\
\hline
\end{tabular}

a. Dependent Variable: EBT

Sumber: Data diolah dengan menggunakan SPSS versi 20

1. Pengujian koefisien regresi variabel ROA:

Menentukan Hipotesis:

- Ho: Secara parsial tidak ada pengaruh signifikan antara ROA dengan EBT.

- Ha: Secara parsial ada pengaruh signifikan antara CR dengan EBT.

Kaidah keputusan:

- Jika nilai $t_{\text {hitung }} \geq t_{\text {tabel }}$, maka Ho ditolak dan Ha diterima, artinya signifikan.

- Jika nilai $\mathrm{t}_{\text {hitung }} \leq \mathrm{t}_{\text {tabel }}$, maka Ho diterima dan Ha ditolak, artinya tidak signifikan.

Dari tabel coefficients (a) diperoleh nilai $t_{\text {hitung }}$ variabel ROA sebesar 1,621 nilai $t_{\text {tabel }}$ dapat dicari sebagai berikut: $\mathrm{t}_{\text {tabel }}=\mathrm{t}_{(\mathrm{a} / 2)(\mathrm{n}-2)}=\mathrm{t}_{(0.05 / 2)(5-2)}=\mathrm{t}_{(0.025)(3)}=3,18245$. Ternyata $\mathrm{t}_{\text {hitung }}<\mathrm{t}_{\text {tabel }}$ $(1,621<3,182)$ maka Ha ditolak, tidak terdapat pengaruh secara signifikan ROA terhadap EBT. 
2. Pengujian koefisien regresi variabel CR:

Menentukan Hipotesis:

- Ho: Secara parsial tidak ada pengaruh signifikan antara CR dengan EBT.

- Ha: Secara parsial ada pengaruh signifikan antara CR dengan EBT.

Kaidah keputusan:

- Jika nilai $t_{\text {hitung }} \geq t_{\text {tabel }}$, maka Ho ditolak dan Ha diterima, artinya signifikan.

- Jika nilai $\mathrm{t}_{\text {hitung }} \leq \mathrm{t}_{\text {tabel }}$, maka Ho diterima dan Ha ditolak, artinya tidak signifikan.

Dari tabel coefficients (a) diperoleh nilai $t_{\text {hitung }}$ variabel CR sebesar 0,186 , nilai $t_{\text {tabel }}$ dapat dicari sebagai berikut: $\mathrm{t}_{\text {tabel }}=\mathrm{t}_{(\mathrm{a} / 2)(\mathrm{n}-2)}=\mathrm{t}_{(0.05 / 2)(5-2)}=\mathrm{t}_{(0.025)(3)}=3,182$. Ternyata $\mathrm{t}_{\text {hitung }}<\mathrm{t}_{\text {tabel }}(0,186<$ 3,182 ) maka Ha ditolak, tidak terdapat pengaruh secara signifikan CR terhadap EBT.

Selanjutnya uji signifikansi silmultan kedua variabel independen terhadapveriabel dependen dengan menganalisis dengan menggunakan tabel ANOVA.

Tabel 8. Uji Statistik F

ANOVA $^{\mathrm{a}}$

\begin{tabular}{|c|c|c|c|c|c|c|}
\hline Model & & $\begin{array}{l}\text { Sum of } \\
\text { Squares }\end{array}$ & $\mathrm{df}$ & Mean Square & $\mathrm{F}$ & Sig. \\
\hline \multirow{3}{*}{1} & Regression &, 448 & 2 & ,224 & 3,062 & $246^{\mathrm{b}}$ \\
\hline & Residual & 146 & 2 &, 073 & & \\
\hline & Total & ,594 & 4 & & & \\
\hline
\end{tabular}

a. Dependent Variable: EBT

b. Predictors: (Constant), CR, ROA

Sumber: Data diolah dengan menggunakan SPSS versi 20

Dari uji ANOVA atau F test di dapat nilai F hitung sebesar 3,062 dengan probabilitas 0,246. Karena nilai probabilitas 0,246>0,05, maka dapat dikatakan bahwa ROAdan CR secara bersamasama atau simultan tidak berpengaruh terhadap EBT.

\section{Kesimpulan}

Dari penjelasan pada bagian sebelumnya dapat disimpulkan bahwa :

Berdasarkan penelitian yang telah dilakukan mengenai pengaruh ROA dan CR terhadap EBT pada PT IMS Jakarta dan analisis yang didukung oleh teori-teori yang melandasi serta hasil pembahasan, maka dapat ditarik kesimpulan dilihat dari besarnya laba perusahaan yang diperoleh dari laporan keuangan selama 5 tahun, laba sebelum pajak berpengaruh tinggi pada tingkat rasio keuangan ROA, namun cukup berpengaruh pada tingkat rasio CR. Kedua variabel memiliki arah positif. 


\section{Daftar Pustaka}

[1] Deviani, M. Y., \& Sudjarni, L. K. (2018). Pengaruh Tingkat Pertumbuhan, Struktur Aktiva, Profitabilitas, Dan Likuiditas Terhadap Struktur Modal Perusahaan Pertambangan Di BEI, EJurnal Manajemen Universitas Udayana, 7(3), 1222-1254.

[2] Hanafi, M. M., \& Halim, A. (2018). Analisis Laporan Keuangan (5th ed.). Yogyakarta: UPP STIM YKPP.

[3] Hery. (2018). Analisis Laporan Keuangan Integrated And Comprehensive Edition (3rd ed.). Jakarta: Grasindo.

[4] Kasmir. (2018). Analisis Laporan Keuangan. Depok: RAJAWALI PERS.

[5] Rohmiyati, Wijayanti, A., \& Nurlaela, S. (2017). Pengaruh Likuiditas, Profitabilitas, Firm Size Dan Growth Terhadap Struktur Modal Pada Perusahaan Kimia Dan Farmasi, Jurnal Ekonomi Paradigma, 19(2), 113-122.

[6] Siswanti, T., \& Kharima. (2016). Analisis Pengaruh Laba Bersih Sebelum Pajak Dan Total Aset Terhadap Return On Assets (ROA) Pada Perusahaan Properti Yang Terdaftar Di Bursa Efek Indonesia Periode 2011-2015, Jurnal Bisnis dan Akuntansi Unisurya, 1(1).

[7] Supena, F. Y. (2018). Pengaruh Rasio Likuiditas, Profitabilitas, Dan Solvabilitas Terhadap Opini Audit Going Concern (Studi Empiris Pada Perusahaan Manufaktur yang Terdaftar di Bursa Efek Indonesia Tahun 2014-2016)[Skripsi]. Bandung (ID): Universitas Widyatama.

[8] Widayanti, R. (2018). Pengaruh Profitabilitas, Likuiditas Dan Leverage Terhadap Financial Distress (Studi pada Sektor Retail yang Terdaftar di Bursa Efek Indonesia Periode 2012-2016)[Skripsi]. Bandung (ID): Universitas Widyatama. 